\title{
FURTHER NOTES ON THE SEXUAL DIMORPHISMS IN JAPANESE SEA URCHINS
}

\section{$\operatorname{AUTHOR}(\mathrm{S})$ :}

Tahara, Yutaka; Okada, Minoru; Kobayashi, Naomasa

\section{CITATION:}

Tahara, Yutaka ... [et al]. FURTHER NOTES ON THE SEXUAL DIMORPHISMS IN JAPANESE SEA URCHINS. PUBLICATIONS OF THE SETO MARINE BIOLOGICAL LABORATORY 1960, 8(1): 183-189

\section{ISSUE DATE:}

1960-05-30

URL:

http://hdl.handle.net/2433/174692

RIGHT: 


\title{
FURTHER NOTES ON THE SEXUAL DIMORPHISMS IN JAPANESE SEA URCHINS ${ }^{13}$
}

\author{
YUTAKA TAHARA \\ Morphological Laboratory, Osaka Liberal Arts University \\ MinORU OKADA \\ Sakuranomiya Junior High School, Osaka City \\ and \\ NAOMASA KOBAYASHI \\ Zoological Institute, Kyoto University
}

With Plates XVIII-XIX and 3 Text-figures

\section{Introduction}

HAMANN (1887) first discovered in Echinocardium mediterraneum that there was a conspicuous sexual dimorphism in the shape of the genital papilla, which is a papilla-like protuberance found on the genital pore of echinoids. Since that discovery, the sexual dimorphism of the genital papilla has been studied in several species of the sea urchin. Recently, TAhara et al. (1958) confirmed this phenomenon in six species of Japanese sea urchins and concluded that the sexual difference of the genital papilla might be classified into the following two types:

a) Mespilia type. The genital papilla of the male is a short, conical protuberance, while that of the female is flat and sunk below the body surface. Psammechinus miliaris (MARx, 1929); Ps. microtuberculatus, Echinus esculentus, Paracentrotus lividus and Spherechinus granularis (SwANN, 1954); Mespilia globulus and Toxopneustes pileolus (TAHARA et al., 1958) belong to this type.

b) Tripneustes type. The genital papilla of the male forms a long tube, whereas that of the female is a short and stumpy protuberance. Echinocardium mediterraneum (HAMANN, 1887); Echinocyamus pussilus (MARx, 1929); Tripneustes gratilla, Echinometra mathaei, Echinostrephus aciculatus and Diadema setosum (TAHARA et al., 1958) belong to this type.

In the present paper are reported the results of further investigations concerning the sexual dimorphisms of five other species of the sea urchin.

1) Contributions from the Seto Marine Biological Laboratory, No. 349.

Publ. Seto Mar. Biol. Lab., VIII (1), 1960. (Article 15) 
The authors are deeply indebted to Dr. Huzio UTinomr and Dr. Takasi Tokioka of the Seto Marine Biological Laboratory of the Kyoto University, Dr. Manabu Kozima of the Sugashima Marine Biological Laboratory of the Nagoya University and Messrs. S. Nishina and S. TAKAMORI of the Naikai Regional Fisheries Research Laboratory Kasaoka Branch, and express their hearty thanks to them for offering conveniences in the course of the present investigations.

\section{Observations}

The present observations were made on the following five species of the sea urchin :

Temnopleurus toreumaticus (KLEIN)

Hemicentrotus pulcherrimus (A. AGASSIZ)

Pseudocentrotus depressus (A. Agassiz)

Anthocidaris crassispina (A. AgAssIz)

Echinocardium cordatum (PENNANT)

Freshly collected materials were observed under the binocular microscope with about twenty magnifications and separated into two groups according to the shape of the genital papilla. Then the determination of the sex of each individual was made by the sexual elements taken at random from its gonads. Furthermore, several other external characters, such as the colour of the spines, of the tube feet, the height of the test (height-diameter ratio) and the size of the genital pores, were examined in order to learn whether there exist any sexual differences or not. The results obtained are presented here separately on each species.

\section{Temnopleurus toreumaticus (KLEIN)}

The genital papilla of the male protrudes on the body surface, forming a short cone. The tip is swollen or tapering off. On the other hand, the genital papilla of the female is flat and membranous, and sunk below the body surface (Text-fig. 1A and B; Pl. XVIII, figs. 1 and 2). In both sexes the genital papilla is colourless and has minute reddish dots.

Moreover, through the microscopic observation of the longitudinal sections of the genital papilla, we found the fact that the wall of the male genital papilla was thicker than that of the female (Pl. XVIII, figs. 3 and 4 ).

Since the sexual difference of the genital papilla is very clear, we can distinguish the two sexes of the living animals with ease and accuracy. We examined fifty-eight individuals in the last summer, and were decieved only one case.

The following five external characters other than the shape of the genital papilla were also examined: the shape and the size of the genital pores, the 
position of the genital pores in the genital plates, the height of the test (heightdiameter ratio) and the colour of the spines. All these characters except the last one show sexual differences.

In male, many individuals have round genital pores, while in female, the genital pores are generally oval or elliptical in shape (Text-fig. $1 \mathrm{C}$ and $\mathrm{D}$ ).

Regarding the sexual dimorphisms in the size and the position of the genital pores and the height of the test, the results of the measurements carried out by

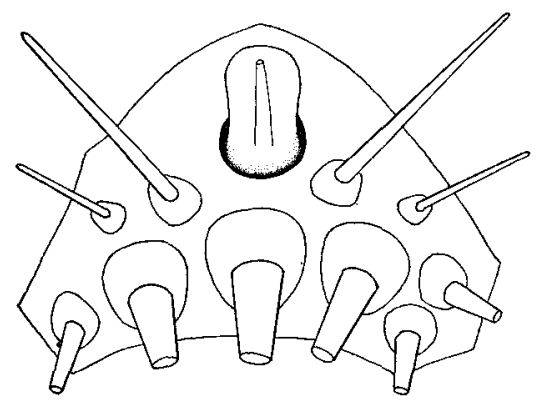

A

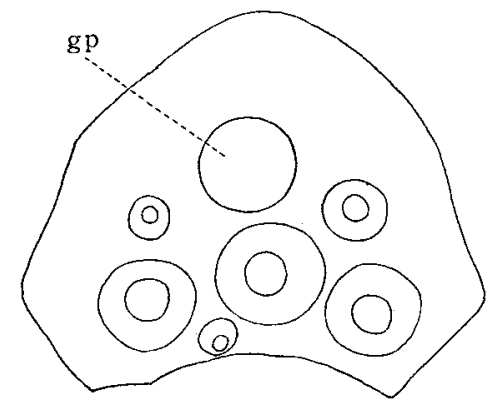

$\mathrm{C}$

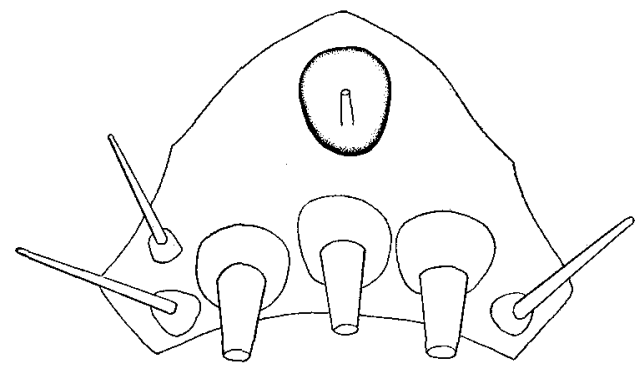

B

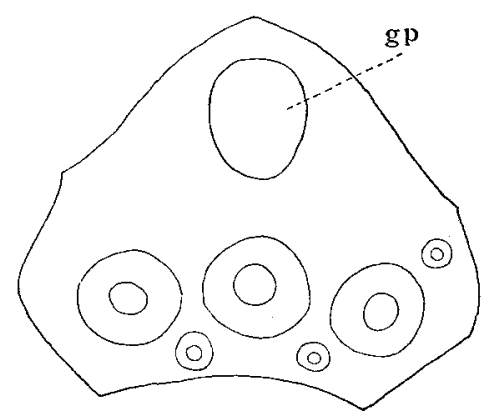

D)

Text-fig. 1. Temnopleurus toreumaticus. A. The fourth genital plate showing the male genital papilla. B. The fifth genital plate showing the female genital papilla. C. The third genital plate showing the male genital pore. D. The third genital plate showing the female genital pore. $g p \cdots$ genital pore.

us confirmed the conclusions drawn by IKEDA (1931) in this species. Namely, the male genital pores are in most cases rather smaller than those of the female and are situated nearly in the center of the genital plates, while the female pores are shifted a little towards the periphery. And the height of the test of the male is generally taller than that of the female. But it should be added here that in spite of this sexual difference in the height of the test, we could not distinguish sexes with accuracy by the shape of the test in this species. 


\section{Hemicentrotus pulcherrimus (A. AGASsIZ)}

The male genital papilla protrudes on the body surface, forming a short cone. On the other hand, the genital papilla of the female is flat and sunk below the body surface (P1. XVIII, figs. 5 and 6). Besides, as is shown in the microphotographs of the longitudinal sections of the genital papilla, the wall of the male genital papilla is thicker than that of the female (Pl. XVIII, figs. 7 and 8).

Other external characters, such as the colour of the spines, of the tube feet, the shape of the genital pores and the height of the test, were examined. Of these, the shape of the genital pores shows a sexual difference; namely, the male genital pores are in most cases oval or elliptical in shape, while those of the

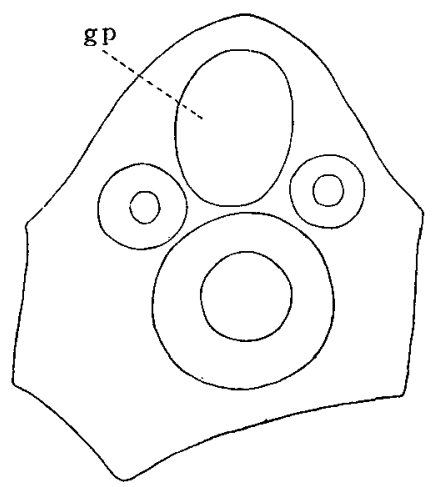

A

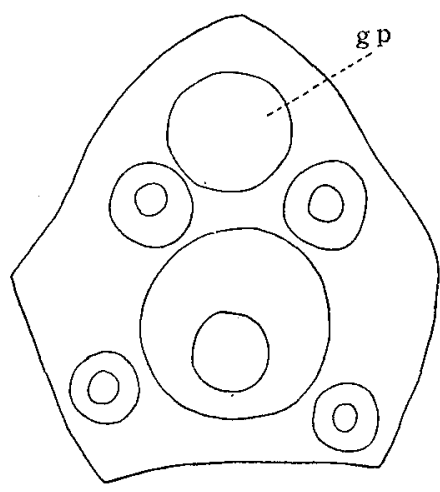

B

Text-fig. 2. Hemicentrotus pulcherrimus. A. The first genital plate showing the male genital pore. 3 . The fourth genital plate showing the female genital pore. $g p \cdots$ genital pore.

female are generally circular (Text-fig. 2). The colour of the tube feet on the oral side shows also the clear sexual dimorphism which was discovered by Motomura (1941). The colour of the spines and the height of the test show no clear sexual differences.

\section{Pseudocentrotus depressus (A. AGASSIZ)}

The genital papilla of the male is a short, stumpy, conical protuberance; while the female papilla is flat and sunk below the body surface (Pl. XIX, figs. 9 and 10 ).

We also examined the colour of the spines and of the tube feet, but could not detect any sexual differences in them. 


\section{Anthocidaris crassispina (A. AGASSIZ)}

In male, the genital papilla is conical and protrudes on the body surface like that of the male of the above mentioned species. In female, the genital papilla is flat and sunk below the body surface in a few individuals, while in many cases it is conical and protrudes on the body surface like that of the male. There is no difference in the colour of the genital papillae of both sexes.

Besides, the minute structures of the genital papilla were examined in longitudinal sections. As can be seen in Figs. 11 and 12 in Pl. XIX, the height of the genital papilla and the thickness of its wall are nearly equal in both specimens and show no clear sexual difference.

We made observations on about one hundred living individuals during two breeding seasons and tried to separate two sexes by the shape of the genital papilla. But we could not distinguish the sexes with accuracy except in cases of a few females which had the typical flat genital papilla. Consequently, we must conclude that the secondary sexual character in the shape of the genital papilla in this species is not so clear as that of many other species.

\section{Echinocardium cordatum (PENNANT)}

In this species, unlike the species above described, the male genital papilla is considerably long, measuring about $2 \mathrm{~mm}$ in length in larger individuals. Its length is always more than half of that of the small spinules which are found

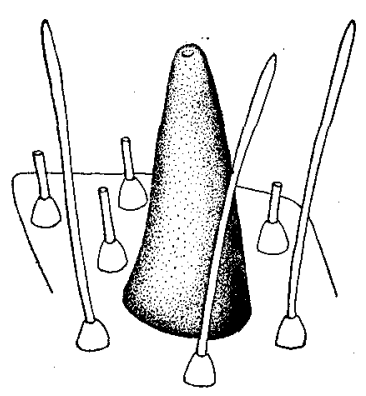

A

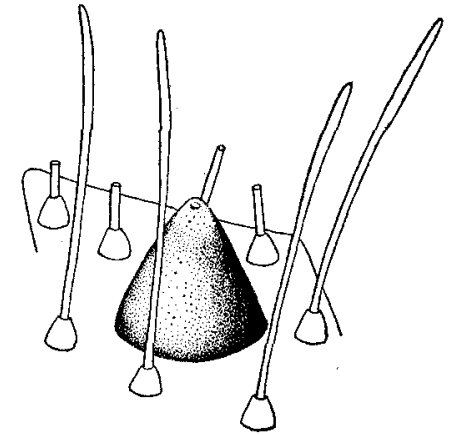

B

Text-fig. 3. Echinocardium cordatum. A. Genital papilla of male. B. Genital papilla of female.

near by the papilla. It is tube-like in shape and tapering off towards end. On the other hand, the female genital papilla is stumpy, conical protuberance. It measures about $0.7 \mathrm{~mm}$ in length in larger individuals. And its length is always less than one-half of that of the neighbouring spinules (Text-fig. 3 and Pl. XIX, 
figs. 13 and 14). We recorded twenty nine cases in all in this species with one error.

Besides, the following individual variations were observed: the shape of the test, the colour of the body and of the gills, and the size of the genital pores. Of these, the size of the genital pores shows a clear sexual difference. We examined seven cases in the male and fourteen in the female and found that the mean values of the ratios of the long diameter of the pore to that of the test are 0.9 percent in the male and 1.2 percent in the female respectively.

\section{Conclusions}

As is clear from the results given above, five species of echinoids reported in this paper may be classified into the two types mentioned in the introduction according to the characteristics of the secondary sexual character in the shape of the genital papilla. Temnopleurus toreumaticus, Hemicentrotus pulcherrimus, Pseudocentrotus depressus and Anthocidaris crassispina belong to the Mespilia type, while Echinocardium cordatum belongs to the Tripneustes type.

Besides, the sexual dimorphisms were found in the shape of the genital pores in Temnopleurus toreumaticus and Hemicentrotus pulcherrimus and in the size of the genital pores in Echinocardium cordatum.

\section{REFERENCES}

HAMANN, O. 1887. Beiträge zur Histologie der Echinodermen. Jena. Zeits. N. F., Vol. 14 (21), pp. 87-266.

IKEDA, H. 1931. A biometric study of the sexual dimorphism and sex ratio in Temnopleurus toreumaticus (Klein). Annot. Zool. Jap., Vol. 13, pp. 233-242.

MARX, W. 1929. Über sekundäre Geschlechtsmerkmale bei Psammechinus miliaris und Echinocyamus pussilus. Zool. Anz., Bd. 80, pp. 331-335.

MoRtensen, TH. 1928-1951. A monograph of the Echinoidea. Vols. I-V. Copenhagen.

MOTOMURA, I. 1941a. The sexual character of the sea urchin, Strongylocentrotus pulcherrimus A. Agassiz. Sci. Rep. Tôhoku Imp. Univ., 4th Ser. Vol. 16, 431.

SWANN, M. M. 1954. Secondary sex differences in five European species of sea-urchin. Pubbl. Stat. Zool. Napoli, Vol. 25, pp. 198-200.

TAHARA, Y., OKADA, M. and KOBAYAshr, N. 1958. Secondary sexual characters in Japanese sea-urchins. Publ. Seto Mar. Biol. Lab., Vol. 7 (1), pp. 165-172.

UTINOMI, H. 1954. A check list of echinoids found in the Kii region. Ibid., Vol. 3 (3), pp. 339-358. 


\section{EXPLANATION OF PLATES XVIII-XIX}

\section{Plate XVIII}

Fig. 1. Temnopleurus toreumaticus; male. Approximately $\times 14$.

Fig. 2. T. toreumaticus; female. Approximately $\times 14$.

Fig. 3. Longitudinal section of the male genital papilla of T. toreumaticus.

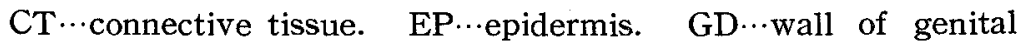

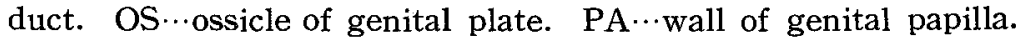
$\times 140$.

Fig. 4. Longitudinal section of the female genital papilla of T.toreumaticus. $\times 140$.

Fig. 5. Hemicentrotus pulcherrimus; Male. Approximately $\times 11$.

Fig. 6. H. pulcherrimus; Female. Approximately $\times 11$.

Fig. 7. Longitudinal section of the male genital papilla of $H$. pulcherrimus. CO $\cdots$ connective tissue. $\times \mathbf{1 7 0}$.

Fig. 8. Longitudinal section of the female genital papilla of $H$. pulcherrimus. $\times 170$.

\section{Pi.ATE XIX}

Fig. 9. Pseudocentrotus depressus; Male. Approximately $\times 12$.

Fig. 10. P. depressus; Female. Approximately $\times 12$.

Fig. 11. Longitudinal section of the male genital papilla of Anthocidaris crassispina. CO $\cdots$ connective tissue. $\times 110$.

Fig. 12. Longitudinal section of the female genital papilla of A. crassispina. $\times \mathbf{1 1 0 .}$

Fig. 13. Echinocardium cordatum; Male. Approximately $\times 10$.

Fig. 14. E. cordatum; Female. Approximately $\times 10$. 

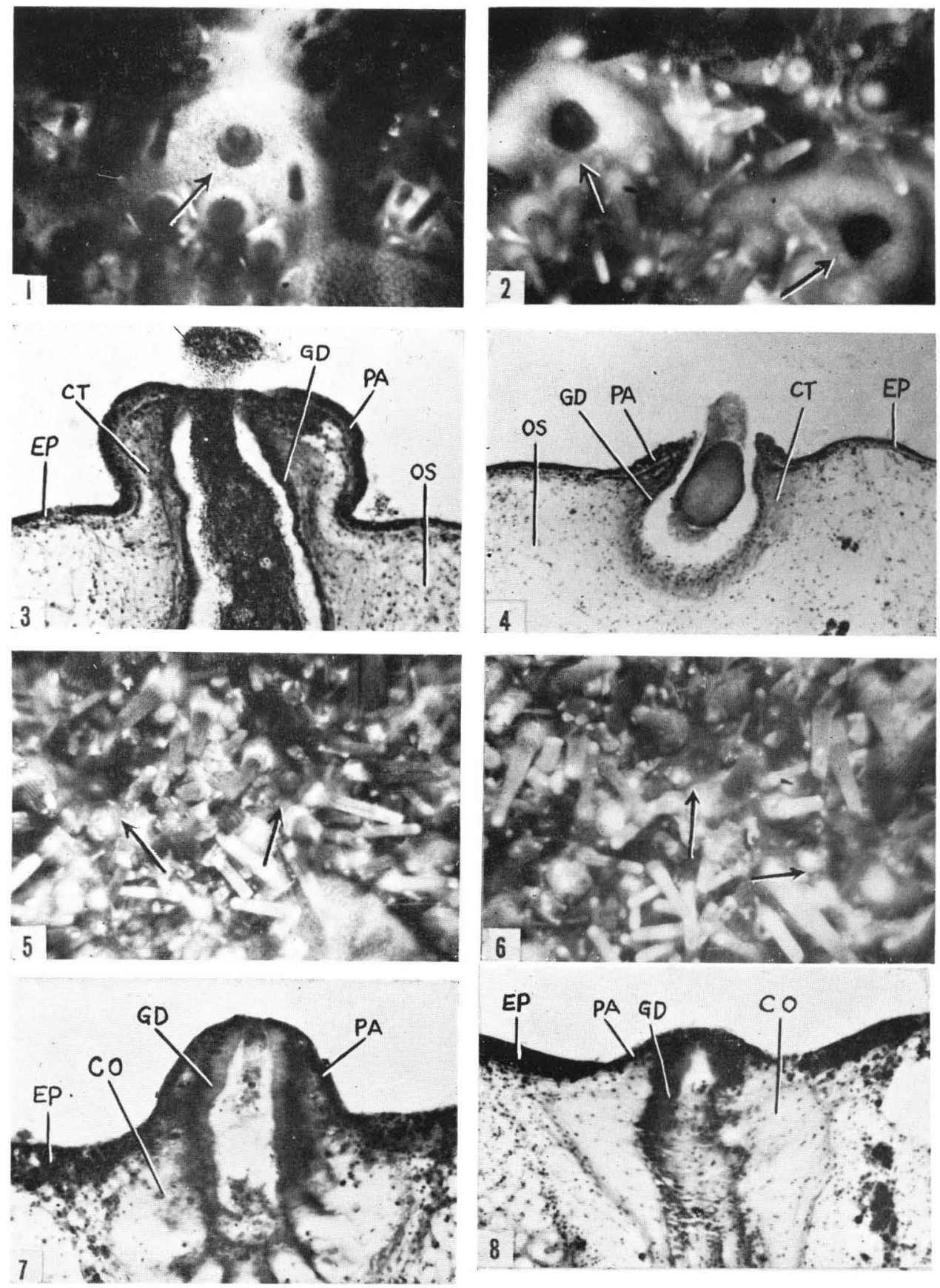

Y. Tahara et al.: Sexual Dimorphisms in Japanese Sea Urchins. 
Publ. Seto Mar. Biol. Lab., VIII, 1 (1960)

PLATE XIX
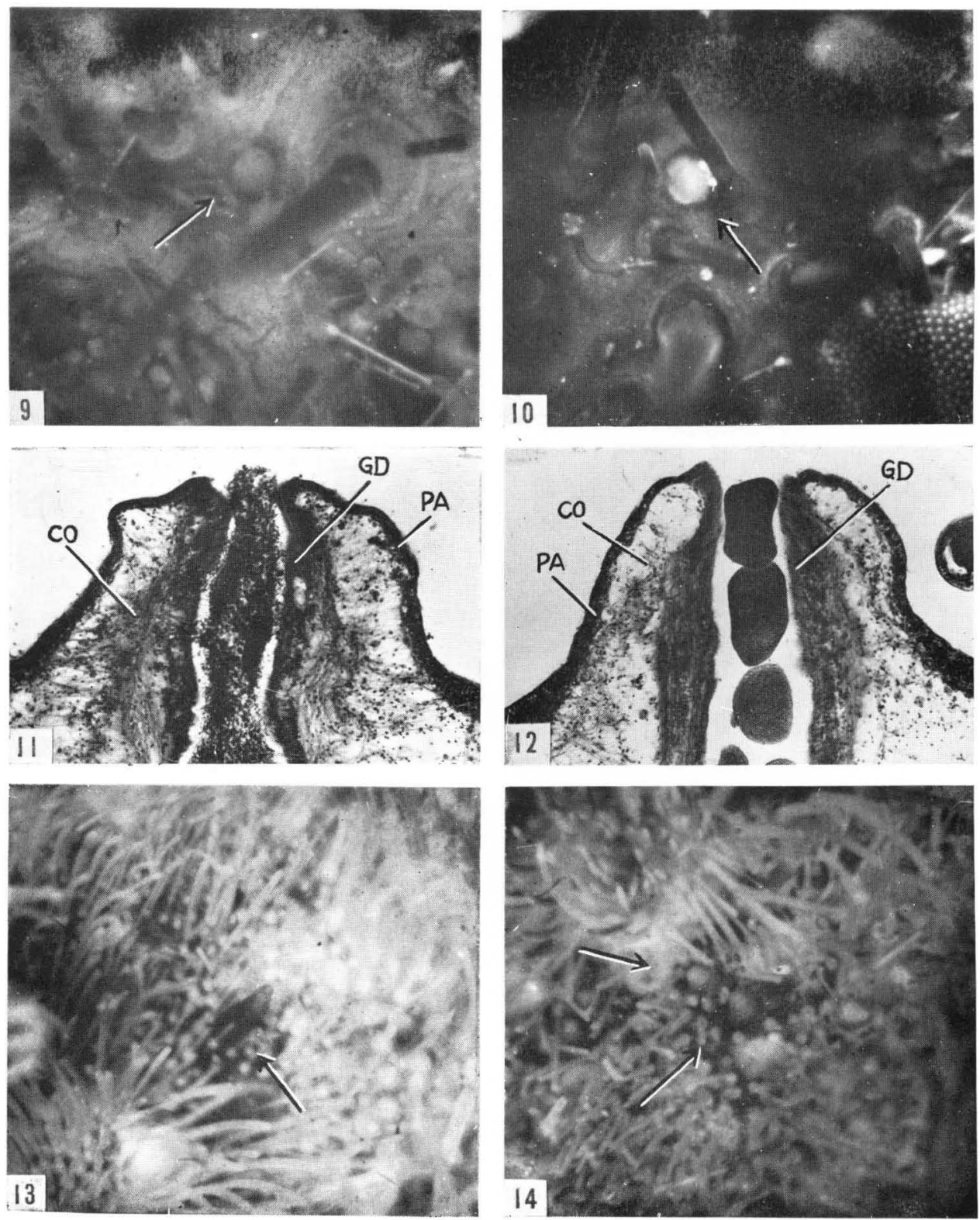

Y. Tahara et al.: Sexual Dimorphisms in Japanese Sea Urchins. 